\title{
DE BETALINGSBALANS EN HET GELDWEZEN VAN SURINAME TIJDENS DE TWEEDE WERELDOORLOG 1)
}

DOOR

H. W. J. BOSMAN

\section{De betalingsbalans.}

Over de ontwikkeling van verschillende bedrijfstakken van Suriname tijdens de oorlogsjaren $1940-1945$ is op het ogenblik wel het voornaamste bekend. Vooral de uitbreiding der bauxietontginning, de achteruitgang van de plantagelandbouw, de aanleg van wegen en defensiewerken en in verband hiermee de toenemende schaarste aan arbeidskrachten vielen op.

In dit artikel willen wij eerst enkele aspecten nog eens nagaan aan de hand van een ruw berekende betalingsbalans en daarna zullen wij enkele monetaire kwesties beschouwen.

Bij het opstellen van een betalingsbalans voor Suriname zijn wij ervan uitgegaan, dat de debetzijde gelijk moet zijn aan de creditzijde, m.a.w. dat een betalingsbalans steeds in evenwicht moet zijn. Is er immers een verschil tussen lopende ontvangsten en uitgaven, dan wordt dit gedekt door goudbeweging of credietverlening.

In dit opzicht vertoonde Suriname's betalingsbalans vóór de jongste oorlog een eigenaardige trek. De invoer overtrof elk jaar de uitvoer en dit verschil werd gedekt door een subsidie van Nederland.

Gaan wij thans na, hoe deze toestand zich ontwikkeld heeft tijdens de oorlog en beschouwen wij daartoe de geconstrueerde betalingsbalans.

1) Dit artikel werd oorspronkelijk geschreven als deel van een scriptie. Ik dank de heren Mr. A. van Traa en W. R. Menkman voor hun waardevolle aanwijzingen. 
Int. betalingsbalans Suriname over de jaren 1940 t/m 1945 (in $f$ 1000)

Ontvangsten

Uitvoer (1)

Kapitaalimport, subsidie enz. door Ned. Regering (2)

Andere kap. imp. (3)

\section{Uitgaven}

60.267 Invoer (4) 83.868

Bijdrage aan de oorlog(5) $\quad 5.000$ - Geschenken aan Neder-

18.824 land in '45 (6)

51.115 Dividend en rente (7)

Kort crediet aan buitenland (8)

130.206
350

30.000

10.988

130.206

De verschillende posten kunnen als volgt verantwoord worden: (1) en (4): totale uit- en invoer 1940/1945, gesommeerd uit de Handelsstatistiek van Suriname.

(2): ontleend aan: „De Rijksfinanciën gedurende de oorlogsjaren 1940-1944", bl. 30. Hier vindt men onder F 2 de uitgaven van de Nederlandse Regering te Londen over de verschillende oorlogsjaren ten behoeve van Suriname, w.o. meest defensieuitgaven. De som bedraagt $£ 2476.900$. Omgerekend tegen een koers van $f 7.60$ is dit het bedrag onder (2).

(3): sluitpost, verkregen door de posten (1) en (2) tezamen af te trekken van de debetzijde.

(5): Ontleend aan een mededeling op bl. 38 van de Rijksbegroting 1947. Dit bedrag werd ,vrijwillig aan de Ned. Regering te Londen afgedragen". Het is niet duidelijk of hier ook de lening onder begrepen is, die tijdens de oorlog in Suriname werd gesloten. Dit is aangenomen.

(6): Ontleend aan een artikel ,,Suriname in oorlogstijd” in ,Commentaar" van 6 Mei 1946.

(7) : Als volgt geschat: Op bl. 169 van zijn boek ,,Suriname 19001940" geeft Mr. A. van Traa enkele getallen, waaruit blijkt, welk deel van de bauxietuitvoer in 1936 en 1937 aan Suriname ten goede kwam in de vorm van belastingen, retributies, lonen, salarissen enz. Dit percentage beliep ongeveer $40 \%$. Als wij nu ditzelfde percentage toepassen op de oorlogsjaren, dan moet van de totale bauxietuitvoer ad $f 52,4$ mill. ongeveer 30 mill. als surplus-waarde voor het buitenland worden gerekend. Dit bedrag omvat dan de rente en het dividend van het in de bauxietontginning gestoken kapitaal. (Aan de Overheid droeg de Surinaamse Bauxite Mij. in deze jaren $f 15$ mill. af, in de vorm van belastingen, concessiegelden, retributies enz.). 
(8): Berekend uit de balansen van 31 Dec. 1945 en 31 Dec. 1939 van De Surinaamse Bank. De posten „Bankiers en Correspondenten" en „Belegging in U.S. Schatkistbiljetten”, balans 1945 debet, werden opgeteld. Daarvan werden afgetrokken „Bankiers en Correspondenten”, balans 1945 credit en dezelfde post op de Balans van 1939 debet. De aldus berekende toename van het deviezenbezit vormt kort crediet aan het buitenland.

Ongetwijfeld zijn verschillende cijfers ruwe benaderingen, maar wij menen, dat deze opstelling op grond van het beschikbare materiaal voldoende verantwoord is.

De post „Andere Kapitaalimport” is eenvoudig als sluitpost genomen, daar debet- en creditzijde immers zoals wij zagen, dezelfde som moeten vertonen.

Deze laatste kapitaalimport van ruim 51 millioen omvat de bouw van de nieuwe bauxietinstallaties van de Surinaamse Bauxite Mij. en de Billiton Mij. en de aanleg van wegen, de uitbreiding van het vliegveld en de bouw van verdedigingswerken, voorzover deze bekostigd werden door de Regering van de Verenigde Staten. Voorzover de Nederlandse Regering dergelijke objecten heeft gefinancierd, vindt men het bedrag hiervoor als deel van de 18,8 millioen van post (2). De gehele kapitaalimport zou dus bijna 70 (nl. 18,8 + 51,1) millioen hebben bedragen, als onder post (2) ook niet enkele zujver consumptieve uitgaven waren voorgekomen, zoals salarissen en dekking van het begrotingstekort van 1940, dat 2 millioen bedroeg. Na 1940 heeft Nederland niet meer hoeven bij te passen.

Wij zullen nu nog nagaan, of dit bedrag van \pm 68 millioen ook niet langs andere weg kan worden berekend. In het Econ. Bericht No. 2 van de Stichting West Indië-Nederland (Dec. 1946) wordt vermeld: „De versterkte bauxiet-ontginning door de Amerikaanse Maatschappij en het aanvatten daarvan door de Billiton-Maatschappij bracht veel geld in omloop en wel ca. Sf 20 millioen ( $\mathrm{Sf}=$ Surinaamse Guldens). Het Amerikaanse leger bracht ca. Sf 12 millioen in circulatie en de bovengenoemde defensiewerken ca. Sf 20 millioen"'. Wij moeten aannemen, dat dit zijn lonen en betaling voor door de bevolking geleverde producten. Een deel van de kapitaalimport zit hier dus in. Het andere deel bestaat voornamelijk uit machines en motoren voor de bouw der fabrieken, defensiewerken enz. benodigd. Wij hebben in de invoerstatistiek nagegaan, wat de waarde was van een aantal in deze jaren ingevoerde goederen, als motoren, machines, 
spoorstaven, stalen platen e.d. Deze greep was natuurlijk tamelijk willekeurig, maar wij hebben juist die goederen genomen, die o.i. voor de investeringen in defensie of bauxietmijnbouw hebben gediend. Wij kwamen op 13 mill. gulden. Dit, gevoegd bij de 52 millioen uitbetaalde lonen geeft 65 millioen als kapitaalimport, welk bedrag dus 3 millioen verschilt met het boven gevonden bedrag. Dit verschil is te verklaren uit de ruwe schattingsmethoden, vooral bij de laatste poging en misschien uit het feit, dat ook consumptiegoederen voor de Amerikaanse troepen zijn ingevoerd, die evenmin betaald behoefden te worden.

Het zou belangwekkend zijn te weten, welk deel van deze kapitaalimport ten goede is gekomen aan de bauxiet-installaties en de wegen, dus productief besteed werd en welk deel aan de defensiewerken. Toch kan gezegd worden, dat het productieapparaat in de oorlogsjaren op deze manier behoorlijk is toegenomen, zij het ook, dat de verwaarlozing der plantages een ernstig interen van kapitaal betekende.

\section{Het geldwezen.}

Het eerste, dat ons opvalt bij een beschouwing over de monetaire ontwikkeling van Suriname in de oorlogsjaren is de geweldige toename van de geldhoeveelheid, die blijkt uit de volgende cijfers, ontleend aan of afgeleid uit de jaarverslagen van de Surinaamse Bank.

\begin{tabular}{|c|c|c|c|}
\hline & 3 I Dec. 1939 & 31 Dec. 1945 & 3 I Dec. I946 \\
\hline Metaalgeld & \pm 2.200 .000 & \pm 2.900 .000 & \pm 2.655 .000 \\
\hline Bankbiljetten & 1.392 .340 & 11.363 .200 & 12.083 .900 \\
\hline Zilverbons & & 576.600 & p.m. \\
\hline \multirow[t]{2}{*}{ Giraalgeld } & 1.019 .929 & 6.365.222 & 6.706 .919 \\
\hline & \pm 4.612 .269 & \pm 21.205 .022 & \pm 21.500 .00 \\
\hline
\end{tabular}

Als ,giraalgeld" is genomen de bedragen op de balans der Surinaamse Bank onder het hoofd: „Rekening-courant saldo's Suriname"'. Hieronder vallen ook kleine bedragen aan termijndeposito's.

Om nu een indruk van het geldteveel te krijgen, zou men deze geldhoeveelheid moeten vergelijken met het nationale inkomen. Dit cijfer is echter voor Suriname niet beschikbaar. Als enige maatstaf hebben wij daarom de Overheidsontvangsten genomen. Wij beseffen zeer wel, dat een verandering in de Overheidsontvangsten niet parallel hoeft te lopen aan een verandering 
in de geldhoeveelheid, al was het alleen maar door invoering van nieuwe en verhoging van bestaande belastingen. Maar toch is er ongetwijfeld enig verband tussen nationaal inkomen en Overheidsontvangsten, zodat we de geldhoeveelheid met de laatste hebben vergeleken. Als geldhoeveelheid hebben we deze keer alleen bankbiljetten en giraalgeld genomen, daar voor de andere geldsoorten geen jaarcijfers beschikbaar waren.

\begin{tabular}{r|c|c|c}
\hline & $\begin{array}{c}\text { I } \\
\text { Bankbiljetten } \\
+ \text { giraalgeld }\end{array}$ & $\begin{array}{c}\text { II } \\
\text { Overheids- } \\
\text { ontvangsten }\end{array}$ & $\frac{\mathrm{I}}{\mathrm{II}} \%$ \\
\hline 1938 & 2210 & 4.243 & 52 \\
39 & 2412 & 4.034 & 60 \\
40 & 3579 & 4.725 & 76 \\
41 & 6398 & 6.941 & 92 \\
42 & 13060 & 10.293 & 127 \\
43 & 18845 & 14.379 & 131 \\
44 & 20958 & 12.995 & 161 \\
45 & 17728 & 7.743 & 229 \\
46 & 18791 & 12.672 & 150
\end{tabular}

Hoe ruw deze maatstaf ook moge zijn, toch ziet men hieruit wel, dat er een grote zwevende koopkracht in Suriname is ontstaan.

Hoe is nu al dit geld in de Surinaamse maatschappij gekomen?

Vooral de bouw der bauxietinstallaties en der defensie-werken, hetzij dat deze productief of improductief waren, heeft zeer veel geld onder de bevolking gebracht. Dit geld werd, zo kunnen wij redeneren, door middel van De Surinaamse Bank en in mindere mate rechtstreeks door het Gouvernement in het verkeer gebracht De circulatiebank kreeg daartegenover deviezen op grond van de kapitaalimport vanuit de Ver.Staten en door de Ned. Regering. Zou voor dit geld voorzover het diende voor loonbetaling, weer worden geïmporteerd, dan zou het vanzelf weer verdwijnen. Inderdaad is er natuurlijk veel meer geïmporteerd dan vroeger, maar weinig aan consumptiegoederen, want er waren maatregelen tot invoerbeperking. Zo ontstond een grote zwevende koopkracht door de hoge lonen, die betaald werden en die voor een deel niet in consumptiegoederen werden omgezet.

Wij hadden een en ander exact willen nagaan aan de hand van een minitieus onderzoek van de balanscijfers der circulatie- 
bank. Dit is echter onmogelijk, o.a. omdat de balans van 1939 de beide kantoren in Amsterdam en Paramaribo tezamen betreft, terwijl voor 1945 balansen zijn opgesteld voor elk kantoor afzonderlijk, vanwege het koersverschil tussen de Surinaamse en Nederlandse gulden. Globaal genomen kunnen we echter zeggen, op grond van de cijfers, dat de deviezenvoorraad van de Surinaamse Bank met ongeveer $f$ 10,6 millioen is toegenomen. Daarvan komt echter 3,2 millioen ten name van het Deviezenfonds, zodat tegenover de rest ad 7,4 millioen nieuw bankgeld in omloop is gekomen, waarvoor niet geïmporteerd is, op de wijze zoals boven beschreven. Dit bedrag vormt dus de zwevende koopkracht.

Verder heeft de Bank sinds de Deviezenverordening van Febr. 1941 al het toen aanwezige en later gewonnen goud aangekocht, zowel ten behoeve van het Deviezenfonds als voor de dekking van haar bankgeld. Niet het gehele bedrag van deze aankopen werkte geldvermeerderend, want een deel van dit goud werd aan tandartsen en goudsmeden verkocht. Op grond van de gegevens op blz. 49 van het verslag der centrale bank over de oorlogsjaren, kan men zeggen, dat de aankoop van ongeveer $1500 \mathrm{~kg}$. stofgoud een netto-inflationnair effect gehad heeft.

Hiervoor werd betaald $f 1.80$ per gram, d.w.z. ongeveer 2,7 mill. gulden.

In het begin van dit hoofdstuk zagen wij, dat de geldsomloop van 4,6 tot 21,1 mill. gestegen is. Van dit verschil van 16,5 mill. is dus 10,1 mill. verklaard door de zojuist besproken twee oorzaken. De verklaring van de overige 6,4 mill. zal wellicht moeten gezocht worden in het gestegen nationaal inkomen. Als men let op de grote bedrijvigheid in deze jaren en op de gestegen lonen, dan is het duidelijk, dat het volksinkomen inderdaad gestegen is, zo al niet reëel, dan toch zeker nominaal.

Ook om die reden moest de circulatie stijgen.

En tenslotte heeft ook de prijsstijging van de ingevoerde goederen invloed op de geldcirculatie gehad.

Volgens het Econ. Bericht no. 2 van de Econ. Stichting WestIndië-Nederland is het indexcijfer voor prijzen van importgoederen gestegen van 100 op 209.

$\mathrm{Er}$ is hier een wisselwerking, want de vermeerderde geldcirculatie heeft weer de neiging de andere prijzen en de lonen te doen stijgen. Toch heeft men deze tendentie behoorlijk in de hand gehouden, hetgeen blijkt uit het feit, dat de index van de levensstandaard op 160 à 165 geschat wordt, als 1939 op 100 


\section{DE BETALINGSBALANS EN HET GELDWEZEN VAN SURINAME}

wordt aangenomen, terwijl de prijzen van de eigen producten gemiddeld 2,5 maal zo hoog kwamen (Zie Econ. Bericht Eswin no. 2).

Hoewel er dus een geweldige zwevende koopkracht aanwezig is, is de omloopsnelheid van het geld gelukkig gering, daar er veel oppotting plaats vindt, vooral door de Brits-Indische bevolking. Verder zijn de prijsregelingen een rem.

$\mathrm{Er}$ is dus een geldteveel, maar dit is niet uitgewerkt en de spiraal van steeds stijgende lonen en prijzen, het duidelijke teken van een acute inflatie, heeft zich in Suriname niet voorgedaan. Men zou echter o.i. een deel van de te grote geldhoeveelheid kunnen wegwerken door de onder het beheer van de Bank zijnde deviezen aan te spreken en hiervoor te importeren. De geimporteerde consumptie- of kapitaalgoederen worden dan immers betaald met de deviezen en de consumenten resp. ondernemers betalen het overtollige geld aan de Bank om die deviezen. te verkrijgen. Natuurlijk kan dit slechts zeer geleidelijk geschieden. In 1946 is de geldhoeveelheid nog iets toegenomen, o.a. door binnenl. credietverlening. De deviezenvoorraad nam af, behalve voor zover het Ned. guldens betrof. 